\title{
Utilization of Organic Fertilizer Made Out of Oil Palm Midrib in Oil Palm Nursery
}

\author{
Mira Ariyanti ${ }^{\# 1}$, Intan Ratna Dewi ${ }^{\#}$, Gita Natali ${ }^{\#}$ \\ ${ }^{*}$ Department of Agronomy, University of Padjadjaran, Sumedang Km 21, Jatinangor, 45363, Indonesia \\ E-mail: ${ }^{1}$ mira.ariyanti@unpad.ac.id; ${ }^{2}$ intan.ratna.dewi@unpad.ac.id
}

\begin{abstract}
Few studies found the organic fertilizer made out of oil palm midrib despite the usage has been performed in many oil palm plantations. Dry and fallen dry oil palm midribs around oil palm are often used as mulch and left alone to be decomposed naturally. This research is aimed to find out the utilization of decomposed oil palm midrib that turned into organic fertilizer which then to is given to oil palm seedling as mix ingredient of organic fertilizer to reduce inorganic fertilizers' usage. Moreover, this treatment is expected to enhance oil palm midrib value as oil palm plantation waste. This experiment was carried out in experimental farm Ciparanje, Faculty of Agriculture Padjadjaran University, Jatinangor, Sumedang District, West Java Province from January to April 2017. The materials are oil palm seedlings from Simalungun varieties from the breeding of Dura and Pisifera, Ultisols order topsoil, NPK 15-15-15 compound fertilizers, organic fertilizer made out of oil palm midribs. The research method was using field experiments with randomized group design with a factorial pattern that consists of two factors. Factor I: Oil Palm Midrib fertilizer dose (P) consists of three levels: $\mathrm{p} 0=0 \mathrm{~g} / \mathrm{polybag}, \mathrm{p} 1=800 \mathrm{~g} / \mathrm{polybag}, \mathrm{p} 2=1600 \mathrm{~g} / \mathrm{polybag}$. Factor II: compound fertilizers dose consists of four levels: $\mathrm{m0}=0 \mathrm{~g} / \mathrm{polybag}, \mathrm{m} 1=20 \mathrm{~g} / \mathrm{polybag}, \mathrm{m} 2=40 \mathrm{~g} / \mathrm{polybag}, \mathrm{m} 3=60 \mathrm{~g} / \mathrm{polybag}$. Organic fertilizer made out of oil palm midrib is causing a good effect on oil palm seedlings growth. The usage application together along with inorganic fertilizers is to add nutrient that needed by plants to reduce inorganic fertilizers. The main focus of this research is sustainable fertilization.
\end{abstract}

Keywords—oil palm seedlings; oil palm nursery; organic fertilizers made out of oil palm midribs; inorganic fertilizers; sustainable fertilization.

\section{INTRODUCTION}

Many problems cause low productivity of oil palm plantation in Indonesia. One of the issues is good cultivation technics that have not been adopted mainly by small estate oil palm plantations. Good cultivation needs to be applied from nursery to harvesting. The nursery is an initial activity that must be started a year before the plant transferred to a field. Seedlings that are used must come from prime and certificated seeds body. Simalungun variety is one of the prime varieties that have $\mathrm{CPO}$ average potential production 8.7 ton/ha/year from Oil Palm Research Center/Pusat Penelitian Kelapa Sawit (PPKS) that have been barcoded by PPKS to prove them as genuine seeds [1].

The critical point of oil palm maintenance is in fertilization which starts from initial nursery to the main nursery; the soil has limited nutrient because plants are planted in polybags [2]. Fertilization becomes very critical to support seedlings growth. Continuous compound fertilizers usage in the long term can cause hardened soil, and nutrient balance will be interrupted [3]. Any efforts to find nutrient resources are important to suppress conventional fertilization costs [4].
In Indonesia, Palm oil generally produced in the form of crude palm oil (CPO) and palm kernel oil (PKO). Recently, CPO value is reaching $712.50 \mathrm{US} \$ /$ ton, while PKO is reaching 1,290 US\$/ton [5] processing fresh fruit bunches that into to crude palm oil daily in the factory producing organic waste. Organic waste which has potential as useful organic materials for the plant has not been used very well [4].

The amount of oil palm midribs for each hectare is about 2.3 tons of dry materials. By calculation, 1 hectare land with 130 oil palm trees will produce 22-26 midribs/year/tree with average weight 4-6 Kgs/midrib/tree. Production of midribs can even reach 40.5 midribs/tree/year with $4.5 \mathrm{kgs} / \mathrm{midrib}$ average weight [6]. Oil palm midribs have benefits value as empty bunches have. According to [7], oil palm midribs contain macronutrient $\mathrm{K}=2.57-3.74 \%, \mathrm{Ca}=0.37-0.68 \%$, and $\mathrm{Mg}=0.13-0.36 \%$. A combination of NPK compound fertilizers and organic fertilizers made out of empty bunches treatment was able to increase seedling heights, oil palm midribs amount, and stem diameters [2]. This research is necessary to find out the correct effect of organic fertilizer made out of oil palm midribs to reduce the usage of NPK compound fertilizers in oil palm nursery. 


\section{MATERIALS AND METHOD}

\section{A. Study Area}

This experiment was carried out in experimental farm Ciparanje, Faculty of Agriculture Padjadjaran University, Jatinangor, Sumedang District, West Java Province. The location of the research is at $\pm 750 \mathrm{~m}$ above sea level. The research was conducted from January to April 2017.

\section{B. Materials}

The materials are oil palm seedlings from Simalungun varieties from the breeding of Dura and Pisifera, Ultisols order topsoil, NPK 15-15-15 compound fertilizers, organic fertilizer made out of oil palm midribs. The tools that were used in the experiment: polybag, hoe, shovel, water bucket, sieve, short hoe, calipers, ruler, stationary (pen, pencil), label, measuring cap, laboratory equipment, analytical scales, and paranet $50 \%$ as shade to protect seedlings from direct sunlight and from rainwater.

\section{Experimental Research}

The research was using field experiments with randomized group design with a factorial pattern that consists of two factors. Factor I: Oil Palm Midrib fertilizer dose $(\mathrm{P})$ consists of three levels: $\mathrm{p} 0=0 \mathrm{~g} /$ polybag, $\mathrm{p} 1=800$ $\mathrm{g} /$ polybag, $\mathrm{p} 2=1600 \mathrm{~g} /$ polybag. Factor II: compound fertilizers dose consists of four levels: $\mathrm{m} 0=0 \mathrm{~g} /$ polybag, $\mathrm{m} 1$ $=20 \mathrm{~g} /$ polybag, $\mathrm{m} 2=40 \mathrm{~g} /$ polybag, $\mathrm{m} 3=60 \mathrm{~g} /$ polybag. There were 12 treatments, and each treatment was repeated three times and each repetition composed of two seedlings. Therefore there were 72 seedlings required.

\section{Data Analysis}

Growth parameter data is analyzed statistically with the $\mathrm{F}$ test (Fisher Exact Test) at 5\% level; if the difference between treatments appears, Scott Knott at level 5\% test will be conducted.

\section{E. Research Execution}

1) Preparation: The seedlings that were used came from sprouts which already planted previously for 3 months during the pre-nursery phase. Soil that used as planting media was Ultisol order topsoil part which was taken from between $10-20 \mathrm{~cm}$ of soil thickness. Firstly, the soil was dried out and then sieved to remove any debris such as wood scraps, gravel or any other unwanted material.

2) Shading: Shading poles were made during the same time with planting preparation or before the sprouts were planted. The shaded pole was made from bamboo with $2 \mathrm{~m}$ long/height. The shade that used was made of paranet $50 \%$. After the sprouts planted for three months, the shade was opened entirely in order the seedlings be able to adapt to the environment.

3) Seedlings maintenance: The seedlings maintenances that were performed are fertilization, weeding, and watering.
The oil palm seedlings require 1.5 liters/plant watering each time with watering interval every other day [8]. Fertilizations were done two weeks after planting transfer or 14 weeks (3 months) after sprouts planting. During prenursery, oil palm seedlings were fertilized by urea, TSP, and $\mathrm{KCl}$ as much as $0.55 \mathrm{~g} /$ plant, $0.68 \mathrm{~g} /$ plant, and $0.14 \mathrm{~g} / \mathrm{plant}$. And then during main nursery fertilization was performed according to the research treatments. The application of organic fertilizer made out of oil palm midribs were performed during planting transfer, while the application of compound inorganic fertilizer NPK were performed in phases (steps) after two weeks of planting transfer of the seedlings with the interval every two weeks.

Weeding was performed by directly pulling out the weeds or manually by hand or by using short hoe. The weeds that growing during pre-nursery phase grew around and outside polybag which potentially impacting the growth of the seedlings and prevent sunlight. Without weeding, the weeds would also become host for pests or diseases.

\section{RESULTS AND DISCUSSION}

From analysis, soil that used as plating media has moderate acidic $\mathrm{pH}$ (5.73), low C-organic (0.99\%), low total $\mathrm{N}(0.15 \%)$, low $\mathrm{C} / \mathrm{N}$ ratio (7), low $\mathrm{P} 2 \mathrm{O} 5$ (5.58 ppm), moderate $\mathrm{K} 2 \mathrm{O}(21.16 \mathrm{mg} / 100 \mathrm{~g})$ and classified as clay which contains $4 \%$ sand, $35 \%$ silt and $61 \%$ clay. Additionally, the soil have cation exchange rate $18.93 \mathrm{cmol}$ $\mathrm{kg}^{-1}$, also exchangeable cations such as $\mathrm{K} 0.13 \mathrm{cmol} \mathrm{kg}^{-1}$ (low), $\mathrm{Na} 0.39 \mathrm{cmol} \mathrm{kg}^{-1}$ (low), Ca $3.07 \mathrm{cmol} \mathrm{kg}^{-1}$ (low), $\mathrm{Mg}$ $2.07 \mathrm{cmol} \mathrm{kg}^{-1}$ (moderate). The soil that is suitable and good for oil palm agriculture is clay texture, KTK $>16 \mathrm{cmol} \mathrm{kg}^{-1}$, optimum $\mathrm{pH}$ for oil palm is 5-6, and $\mathrm{C}$ organic $>0.8 \%$ [9].

Based on the analysis, organic fertilizer made out of oil palm midrib contains $34.8 \%$ organic C, $0.98 \% \mathrm{~N}, 0.53 \%$ $\mathrm{P} 2 \mathrm{O} 5$, and $0.28 \% \mathrm{~K} 2 \mathrm{O}$ while inorganic fertilizer contains $21 \% \mathrm{~N}, 15 \% \mathrm{P} 2 \mathrm{O} 5$, and $18 \% \mathrm{~K} 2 \mathrm{O}$. Effect of organic fertilizer made out of oil palm midribs and inorganic fertilizer treatment in different dose on oil palm seedlings growth is explained as follows:

\section{A. Plant height and trunk}

Increment of oil palm seedlings height and trunk with different fertilizer treatment is showed in Table I and Fig. 1. The tallest seedlings produced with C treatment (40 g NPK fertilizer/plant) which is generally recommended oil palm seedling fertilization and followed by treatment $G(800$ $\mathrm{g}$ /plant organic fertilizer made out of oil palm midribs $+40 \mathrm{~g}$ NPK fertilizer) and treatment D (60 g/plant NPK fertilizer). Best trunk growth is produced by $\mathrm{L}$ treatment $(1600 \mathrm{~g} / \mathrm{plant}$ organic fertilizer made out of oil plant midribs $+60 \mathrm{~g}$ NPK fertilizer). Treatment with only organic fertilizer made out of oil palm midribs has not been able to increase trunk growth as good as treatment with recommended NPK fertilization. Genetically, oil palm trunk growth range in $1.07 \mathrm{~cm}-1.83$ $\mathrm{cm}$ in every three months or $0.35 \mathrm{~cm}-0.61 \mathrm{~cm}$ in each month. 
TABLE I

OIL PALM SEEDLINGS HEIGHT AND TRUNKS WITH DIFFERENT FERTILIZATION TREATMENT IN 12 WAT

\begin{tabular}{|c|c|c|}
\hline Treatments & Height (cm) & Trunk (cm) \\
\hline$A=$ No Fertilizer & 7.43 & 1.18 \\
\hline $\mathrm{B}=20 \mathrm{~g} / \mathrm{plant}$ NPK Compound Fertilizer & 7.98 & 1.08 \\
\hline $\mathrm{C}=40 \mathrm{~g} /$ plant NPK Compound Fertilizer & 12.30 & 1.67 \\
\hline $\mathrm{D}=60 \mathrm{~g} /$ plant NPK Compound Fertilizer & 10.13 & 1.52 \\
\hline $\mathrm{E}=800 \mathrm{~g} /$ plant organic fertilizer made out of oil palm midribs & 6.55 & 1.37 \\
\hline $\mathrm{F}=800 \mathrm{~g} /$ plant organic fertilizer made out of oil palm midribs $+20 \mathrm{~g} / \mathrm{plant} \mathrm{NPK}$ & 8.33 & 1.52 \\
\hline $\mathrm{G}=800 \mathrm{~g} /$ plant organic fertilizer made out of oil palm $+40 \mathrm{~g} / \mathrm{plant} \mathrm{NPK}$ & 10.30 & 1.63 \\
\hline $\mathrm{H}=800 \mathrm{~g} /$ plant organic fertilizer made out of oil palm $+60 \mathrm{~g} / \mathrm{plant} \mathrm{NPK}$ & 5.47 & 1.38 \\
\hline $\mathrm{I}=1600 \mathrm{~g} /$ plant organic fertilizer made out of oil palm & 3.35 & 1.07 \\
\hline $\mathrm{J}=1600 \mathrm{~g} /$ plant organic fertilizer made out of oil palm $+20 \mathrm{~g} / \mathrm{plant} \mathrm{NPK}$ & 7.28 & 1.50 \\
\hline $\mathrm{K}=1600 \mathrm{~g} /$ plant organic fertilizer made out of oil palm $+40 \mathrm{~g} / \mathrm{plant} \mathrm{NPK}$ & 6.28 & 1.65 \\
\hline $\mathrm{L}=1600 \mathrm{~g} /$ plant organic fertilizer made out of oil palm $+60 \mathrm{~g} / \mathrm{plant} \mathrm{NPK}$ & 7.23 & 1.83 \\
\hline F-test & $*$ & $\mathrm{Ns}$ \\
\hline $5 \%$ Scott Knott & 30.38 & 1.56 \\
\hline $\mathrm{CV} \%$ & 9.67 & 8.72 \\
\hline
\end{tabular}

WAT : weeks after treatment, $*=$ significantly different, ns : non-significant

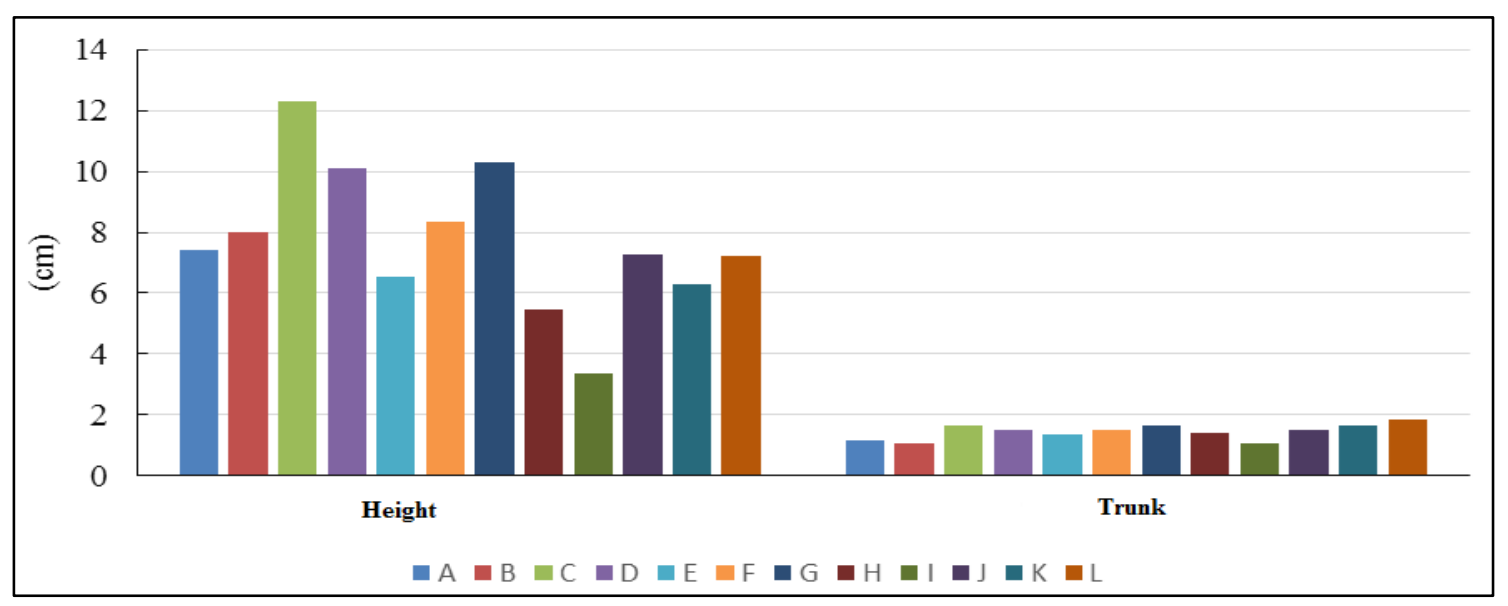

Fig. 1 Oil Palm Seedlings Height and Trunks with different fertilizing treatment

\section{B. Root and Shoot Dry Weight}

Table II shows that fertilization (treatment) is affecting dry shoot weight more compared with root dry weight. G treatment $(800 \mathrm{~g} /$ plant organic fertilizer made out of oil palm + $40 \mathrm{~g} /$ plant NPK), J treatment (1600 g/plant organic fertilizer made out of oil palm $+20 \mathrm{~g} /$ plant NPK) and L treatment $(1600 \mathrm{~g} /$ plant organic fertilizer made out of oil palm $+60 \mathrm{~g} /$ plant NPK) produced plant with better shoot dry weight compared with other treatments. Fertilization appeared to not affecting on root dry weight. $1600 \mathrm{~g} / \mathrm{plant}$ organic fertilizer mixed with $60 \mathrm{~g} /$ plant inorganic fertilizer tend to give good oil palm root dry weight.

TABLE II

Oil Palm Shoot and Root Dry Weight with DifFerent Fertilizer TREatMent IN 12 WAT (CM)

\begin{tabular}{|c|c|c|}
\hline Treatment & Shoot Dry Weight (g) & Root Dry Weight (g) \\
\hline$A=$ No Fertilizer & $3.13 \mathrm{~d}$ & $1.92 \mathrm{a}$ \\
\hline $\mathrm{B}=20 \mathrm{~g} / \mathrm{plant}$ NPK Compound Fertilizer & $4.27 \mathrm{~cd}$ & $1.67 \mathrm{a}$ \\
\hline $\mathrm{C}=40 \mathrm{~g} / \mathrm{plant}$ NPK Compound Fertilizer & $6.08 \mathrm{bcd}$ & $2.62 \mathrm{a}$ \\
\hline $\mathrm{D}=60 \mathrm{~g} /$ plant NPK Compound Fertilizer & $5.61 \mathrm{bcd}$ & $2.02 \mathrm{a}$ \\
\hline $\mathrm{E}=800 \mathrm{~g} /$ plant organic fertilizer made out of oil palm midribs & $4.13 \mathrm{~cd}$ & $2.03 \mathrm{a}$ \\
\hline $\mathrm{F}=800 \mathrm{~g} /$ plant organic fertilizer made out of oil palm midribs $+20 \mathrm{~g} / \mathrm{plant}$ NPK & $4.27 \mathrm{~cd}$ & $2.46 \mathrm{a}$ \\
\hline $\mathrm{G}=800 \mathrm{~g} /$ plant organic fertilizer made out of oil palm $+40 \mathrm{~g} / \mathrm{plant} \mathrm{NPK}$ & $7.47 \mathrm{abc}$ & $2.50 \mathrm{a}$ \\
\hline $\mathrm{H}=800 \mathrm{~g} /$ plant organic fertilizer made out of oil palm $+60 \mathrm{~g} / \mathrm{plant} \mathrm{NPK}$ & $5.48 \mathrm{bcd}$ & $2.27 \mathrm{a}$ \\
\hline $\mathrm{I}=1600 \mathrm{~g} /$ plant organic fertilizer made out of oil palm & $3.51 \mathrm{~d}$ & $1.92 \mathrm{a}$ \\
\hline $\mathrm{J}=1600 \mathrm{~g} /$ plant organic fertilizer made out of oil palm $+20 \mathrm{~g} /$ plant NPK & $7.74 \mathrm{ab}$ & $3.46 \mathrm{a}$ \\
\hline $\mathrm{K}=1600 \mathrm{~g} /$ plant organic fertilizer made out of oil palm $+40 \mathrm{~g} /$ plant NPK & $4.25 \mathrm{~cd}$ & $1.87 \mathrm{a}$ \\
\hline $\mathrm{L}=1600 \mathrm{~g} /$ plant organic fertilizer made out of oil palm $+60 \mathrm{~g} / \mathrm{plant}$ NPK & $9.84 \mathrm{a}$ & $3.83 \mathrm{a}$ \\
\hline F test & * & ns \\
\hline $5 \%$ Scott Knott & 3.37 & 2.26 \\
\hline $\mathrm{CV} \%$ & 17.33 & 15.98 \\
\hline
\end{tabular}

WAT : weeks after treatment, $*$ = significantly different, $\mathrm{ns}:$ non-significant 


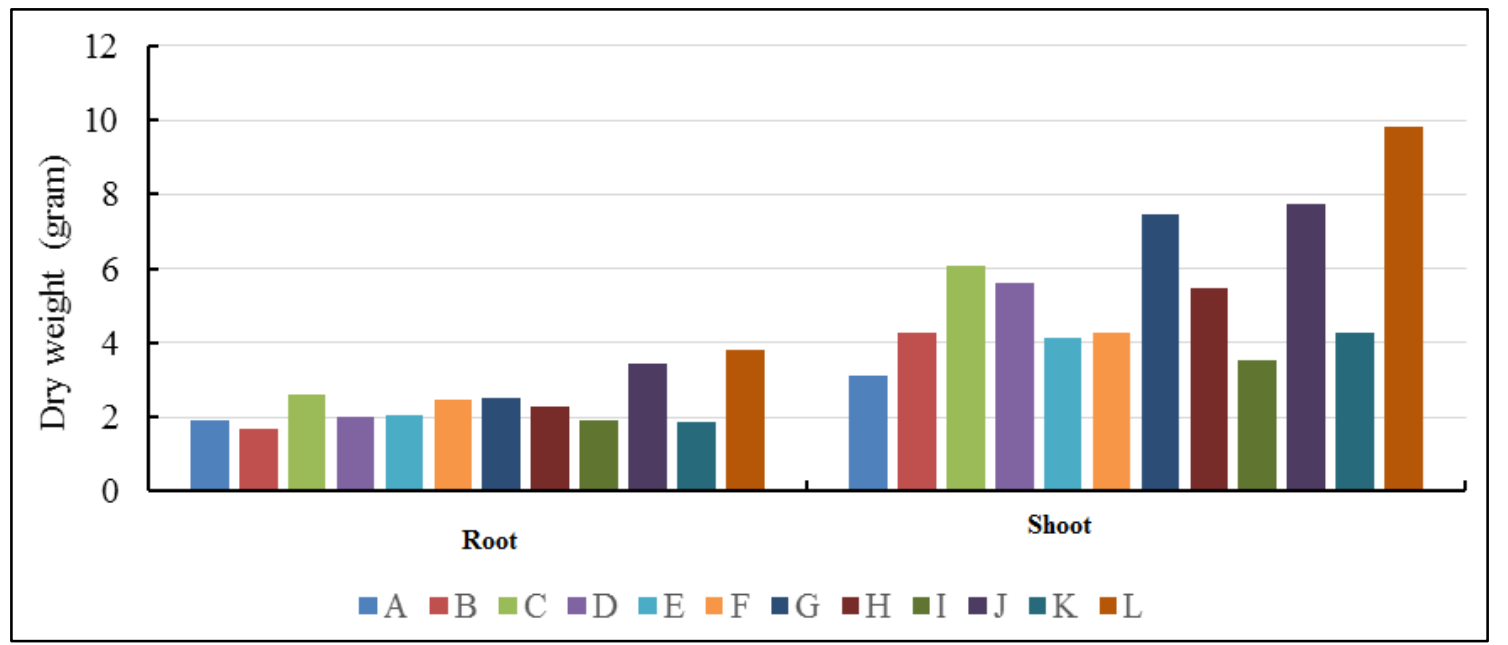

Fig. 2 Oil Palm Shoot and Root Dry Weight with Different Fertilizer Treatment

\section{Area and number of leaf:}

Table III shows that $\mathrm{L}$ treatment $(1600 \mathrm{~g} / \mathrm{plant}$ organic fertilizer made out of oil palm $+60 \mathrm{~g} / \mathrm{plant}$ NPK) resulted in the widest leaf area but not significantly different compared with plants with $\mathrm{G}$ treatment $(800 \mathrm{~g} /$ plant organic fertilizer made out of oil palm $+40 \mathrm{~g} / \mathrm{plant} \mathrm{NPK})$. In this situation, treatment $\mathrm{G}$ can be considered more effective. High $\mathrm{N}$ content whether in organic fertilizer made out of midribs $(0.98 \%)$ or in inorganic fertilizers $(12 \%)$ shows that the higher fertilizer dose on treatment the higher $\mathrm{N}$ contribution on plant growth, especially in wider leaf. $\mathrm{N}$ treatment can increase leaf productivity, area, and assimilate rate level on oil palm [10]. Leaf area represents leaf photosynthesis area. Therefore, the wider leaf area is the higher photosynthesis process rate. Leaf area and vegetative growth are increasing by nitrogen treatment at nursery.

Regarding leaf growth, nutrient treatment through fertilization will have more visible effect toward leaf area increment compared with leaf quantity. Plant growth is the effect of interactions between genetic and environmental factors that synergized to determine growth process. Genetic factors are more dominant affecting how many leaves that formed during a specified period. This is especially true in the nursery phase when plants are conditioned in a relatively identical environment because they tend to be planted on one nursery land. Oil palm leaf number tends to be more affected by genetic factors and also depend upon plant age [11]. Table III shows that oil palm seedlings leaf number are increment about 2.15 leaves/ months.
TABLE III

OIl PALM SEedlings LEAF AREA AND NUMBER WiTH DifFERENT FERTILIZER TREATMENT IN 12 WAT

\begin{tabular}{|c|c|c|}
\hline Treatment & $\begin{array}{c}\text { Leaf area } \\
\left(\mathrm{cm}^{2}\right)\end{array}$ & $\begin{array}{c}\text { Leaf } \\
\text { number } \\
\text { (leaf) }\end{array}$ \\
\hline$A=$ No Fertilizer & $45.55 \mathrm{bc}$ & 2.00 \\
\hline $\mathrm{B}=20 \mathrm{~g} /$ plant NPK Compound Fertilizer & $41.06 \mathrm{bc}$ & 1.17 \\
\hline $\mathrm{C}=40 \mathrm{~g} /$ plant NPK Compound Fertilizer & $36.34 \mathrm{bc}$ & 3.17 \\
\hline $\mathrm{D}=60 \mathrm{~g} /$ plant NPK Compound Fertilizer & $57.89 \mathrm{abc}$ & 2.33 \\
\hline $\begin{array}{c}\mathrm{E}=800 \mathrm{~g} / \text { plant organic fertilizer made out } \\
\text { of oil palm midribs }\end{array}$ & $44.99 \mathrm{bc}$ & 2.3 \\
\hline $\begin{aligned} \mathrm{F}= & 800 \mathrm{~g} / \text { plant organic fertilizer made } \\
& \text { out of oil palm midribs }+20 \mathrm{~g} / \text { plant } \\
& \text { NPK }\end{aligned}$ & $49.89 \mathrm{bc}$ & 2.50 \\
\hline $\begin{array}{c}\mathrm{G}=800 \mathrm{~g} / \text { plant organic fertilizer made } \\
\text { out of oil palm }+40 \mathrm{~g} / \text { plant NPK }\end{array}$ & $67.23 \mathrm{ab}$ & 2.00 \\
\hline $\begin{array}{c}\mathrm{H}=800 \mathrm{~g} / \text { plant organic fertilizer made } \\
\text { out of oil palm }+60 \mathrm{~g} / \text { plant NPK }\end{array}$ & $53.12 \mathrm{abc}$ & 2.50 \\
\hline $\begin{array}{l}\mathrm{I}=1600 \mathrm{~g} / \text { plant organic fertilizer made } \\
\text { out of oil palm }\end{array}$ & $34.22 \mathrm{c}$ & 1.67 \\
\hline $\begin{array}{c}\mathrm{J}=1600 \mathrm{~g} / \text { plant organic fertilizer made } \\
\text { out of oil palm }+20 \mathrm{~g} / \text { plant NPK }\end{array}$ & $55.15 \mathrm{abc}$ & 2.17 \\
\hline $\begin{array}{c}\mathrm{K}=1600 \mathrm{~g} / \text { plant organic fertilizer made } \\
\text { out of oil palm }+40 \mathrm{~g} / \text { plant NPK }\end{array}$ & $40.09 \mathrm{bc}$ & 2.17 \\
\hline $\begin{array}{r}\mathrm{L}=1600 \mathrm{~g} / \text { plant organic fertilizer made } \\
\text { out of oil palm }+60 \mathrm{~g} / \mathrm{plant} \text { NPK }\end{array}$ & $82.59 \mathrm{a}$ & 1.83 \\
\hline F test & $*$ & ns \\
\hline $5 \%$ Scott Knott & 2.18 & 1.32 \\
\hline $\mathrm{CV} \%$ & 16.03 & 15.24 \\
\hline
\end{tabular}

WAT: weeks after treatment, $*=$ significantly different, ns: nonsignificant

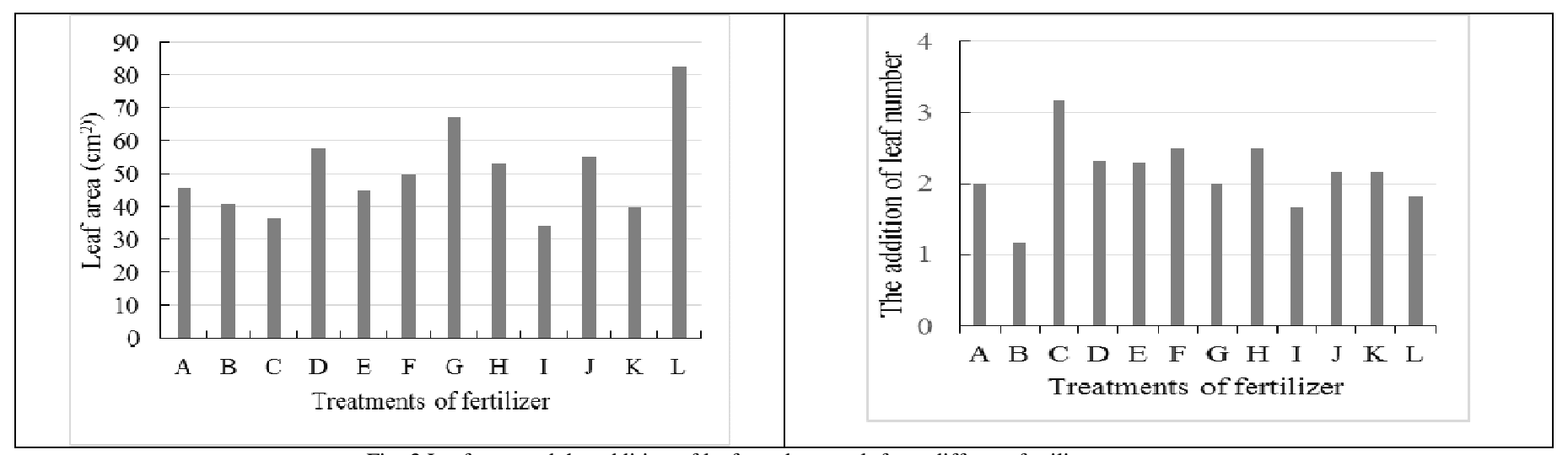

Fig. 3 Leaf area and the addition of leaf number result from different fertilizer treatments 
Treatment at $800 \mathrm{~g}$ organic fertilizer made out of oil palm midribs, height increment of oil palm seedling is rising along with the raising of inorganic fertilizers treatment (Fig. 1), and at $1600 \mathrm{~g}$ dose of organic fertilizer made out of oil palm midribs, inorganic fertilizer did not give much effect. It shows that the dose increment of organic fertilizer made out of oil palm midribs will suppress the use of inorganic fertilizers because the plant's needs of nutrients are starting to be fulfilled primarily to support plant height growth. The higher the organic fertilizers dose, the more nutrient content that it will be more able to fulfill the plant needs of the nutrient. $\mathrm{G}$ treatment ( $800 \mathrm{~g} / \mathrm{plant}$ organic fertilizer made out of oil palm $+40 \mathrm{~g} /$ plant NPK) affected well to plant growth especially the height of oil palm seedlings until the age of 4 months.

Organic fertilizer made out of oil palm midribs contains $0.98 \% \mathrm{~N}$ (nitrogen) which has an important role in plant height growth. According to [12], $\mathrm{N}$ is nutrient that important for plant growth, lack of $\mathrm{N}$ can cause abnormal plant growth or stunted plants. $\mathrm{N}$ nutrient can stimulate entirely plant growth especially stem of oil palm [13]. According to [14], $\mathrm{N}$ nutrient is tightly correlated with meristem tissues; therefore it will determine plant growth. Based on the analysis, organic fertilizer made out of oil palm midribs contain $34.8 \%$ organic $\mathrm{C}, 0.98 \% \mathrm{~N}, 0.53 \% \mathrm{P} 2 \mathrm{O}$, and $0.28 \% \mathrm{~K} 2 \mathrm{O}$ while inorganic fertilizers contain $21 \% \mathrm{~N}$, $15 \% \mathrm{P} 2 \mathrm{O} 5,18 \% \mathrm{~K} 2 \mathrm{O}$. Due to low nutrient content in organic fertilizer made out of oil palm midribs, the addition of inorganic fertilizers is still needed to fulfill nutrients supply. Oil palm needs nutrient contained in inorganic fertilizers to support plant height growth especially $\mathrm{N}$ nutrient (at $40 \mathrm{~g} \mathrm{NPK} /$ plant dose) which in inorganic fertilizers it is (the nutrient) is quickly more available for the plant. Dose increment to $60 \mathrm{~g} / \mathrm{plant}$ did not perform better effect on plant height. Treatment with $60 \mathrm{~g} / \mathrm{plant}$ inorganic fertilizers gave no significant increment of plant height compared with $800 \mathrm{~g} /$ plant organic fertilizers made out of oil palm midribs combined with NPK $40 \mathrm{~g} /$ plant treatment (Table 1).

At normal plant growth, height growth is typically occurring together with trunk diameter growth to increase its supporting power which then avoids it from falling. The trunk represents plant nutrients. Trunk growth condition is related with plant age [15]. The growth of oil palm trunk until four months old is between $1.08-1.83 \mathrm{~cm}$. Plant growth mainly them stem is slower because it is affected by plant genetic factors [16]. Trunk growth tended to be better with fertilization activity compared with no fertilization, especially with $40 \mathrm{~g} /$ polybag and $60 \mathrm{~g} /$ polybag inorganic fertilizers treatment. Likewise, organic fertilizers treatment whether singular or mixed with inorganic fertilizers especially L treatment (1600 g/plant organic fertilizer made out of oil palm $+60 \mathrm{~g} /$ plant NPK) resulted in good trunk growth (Table I). Organic materials are also supplied macro and micronutrients needed by plants, and able to substitute nutrients from inorganic fertilizers [17]. N, P, K, and $\mathrm{Mg}$ nutrients treatment is significantly affecting dry plant material forming [18]. Plant upper part (shoot) dry weight describes accumulated dry material on that part. The higher plant dry weight shows that the better plant is in absorbing the nutrient. Organic fertilizers are significantly affecting leaf dry weight, wet leaf weight, root wet weight, root dry weight, and stem dry weight of oil palm [19]. The addition of nutrients contained in organic fertilizers is causing a response in the form of increment in vegetative growth which is possibly increasing in the growing oil palm.

NPK compound fertilizers treatment can affect leaf organ performance to help photosynthesis in producing photosynthesis. Plants are tending to keep biomass in shoots [20]. Shoot function is to provide carbohydrate through photosynthesis. $\mathrm{G}$ treatment $(800 \mathrm{~g} /$ plant organic fertilizer made out of oil palm $+40 \mathrm{~g} / \mathrm{plant}$ NPK) is the most efficient treatment in producing a plant with better shoot dry weight.

Root growth will be described through accumulated dry material in roots, which $\mathrm{L}$ treatment $(1600 \mathrm{~g} / \mathrm{plant}$ organic fertilizer made out of oil palm $+60 \mathrm{~g} /$ plant NPK) generated root with moderate dry weight. Sufficient nutrient supply supported by the optimum environment and sufficient water availability will provide good environment for the growth of oil palm seedlings roots. The highest dose of organic and inorganic fertilizers in this situation seems to be used optimally by roots to stimulate root parts growth. Root as an organ that has the function as nutrient and water absorber from the ground has to have strong growth. Strong roots will be able to support the upper plant to live.

Increment of leaf area seems to synergize with accumulated dry weight on the shoot, which $\mathrm{G}$ treatment (800 g/plant organic fertilizer from oil palm $+40 \mathrm{~g} / \mathrm{plant}$ NPK) can supply nutrients that needed by plant especially in widening leaf area. Optimum leaf area enables sufficient sunlight captured for photosynthesis which in the end related to leaf chlorophyll as main element for the plant to photosynthetic. Leaf area describes how much leaf part that photosynthetic, therefore the wider leaf area, the higher rate of the photosynthesis process.

$\mathrm{G}$ treatment ( $800 \mathrm{~g} /$ plant organic fertilizer made out of oil palm $+40 \mathrm{~g} /$ plant NPK) is effective in raising leaf area about $85 \%$ compared with plant treated with singular fertilization using only $40 \mathrm{~g}$ NPK/ plant. Likewise so does organic fertilizers made out of oil palm midribs singular treatment only at $800 \mathrm{~g} / \mathrm{plant}$ dose level, or $1600 \mathrm{~g} / \mathrm{plant}$ has not resulted to better leaf area growth compared with an organic fertilizer that given together with inorganic fertilizers NPK $60 \mathrm{~g} /$ plant (Table III). This condition shows that organic fertilizers and inorganic fertilizers are complementing each other in providing nutrients needed by oil palm seedlings. Organic material treatment (oil palm empty bunches and stem ash) with a half dose of oil palm fertilization recommendation resulting non-significant leaf area compare with recommended dose treatment [21]. Increment of leaf area is affected by nutrients availability such as nitrogen, where organic fertilizers made out of oil palm midribs treatment along with inorganic fertilizers were able to provide sufficient $\mathrm{N}$ for plants. Nitrogen function is to raise plant vegetative growth especially on a leaf [22]. The increment of leaf area is affected by nutrients especially nitrogen [23].

Leaf numbers growth is more affected by plant genetic condition, which is a leaf growing ability for each plant is different. The increment of oil palm leaf numbers in 3 months ranged between 1.17- 3.17 leaves and not affected by fertilization treatment type. The leaf forming rate is 
constant if plants are growing in constant sunlight intensity and temperature [11].

Inorganic fertilizers are indeed commonly used in Indonesia oil palm plantations to support plant growth. Besides easy to use and cheap, inorganic fertilizers treatment is also able to supply nutrients needed by plants in the available state quickly. One of negative effect that might appear in continuously inorganic fertilizers treatment is hardened plant medium caused by inorganic fertilizers residue that clog on soil pores, therefore, will reduce soil fertility. A further effect is that inorganic fertilizers do not support sustainable oil palm plantations. The use of oil palm midribs as fertilizer material has not been applied especially in the nursery. This experiment is expected to be a good initial step in supporting the ISPO (Indonesian Sustainable Palm Oil) concept.

\section{IV.CONCLUSION}

Fertilizers as nutrients supplement for plants need to have its concern according to its origin material. Inorganic fertilizers that applied by many oil palm plantation practitioners is meet the standards if it reviewed from its practical and nutrients availability, but if it excessively applied, it will cause an unfortunate effect on plants and soils. Alternative fertilizers are needed to equalize the usage of inorganic fertilizers especially for oil palm in the nursery phase. The combination between organic fertilizers made out of oil palm midribs ( $800 \mathrm{~g} /$ plant) with inorganic fertilizers in NPK compound form (40 g/plant) effectively resulted in well oil palm seedlings that are represented in plant height, shoot and root dry weight parameters.

\section{ACKNOWLEDGMENT}

The writer would like to give best regards to Padjadjaran University that has funded this whole research through University Fundamental Research scheme on UNPAD Internal Grant 2017.

\section{CONFLICT OF INTEREST}

Oil palm world is enlivened by the rules that requiring a sustainable term in oil palm plantations. In Indonesia, the rule is known as Indonesian Sustainable Palm Oil (ISPO) and in international scale is known as RSPO (Roundtable Sustainable Palm Oil). Environment-friendly aspect becomes an important point that needs to be considered in cultivation techniques. Aspects that studied here is fertilization as nutrients supplement for plants. Oil palm plantations are commonly used inorganic fertilizers for its practicality in applications and transportation, easy to find, quickly available nutrients for plants, and easy to absorb. Negative effects of excessive usage of inorganic fertilizers are soil medium fertility degradation, soil pollution because soil from the medium is usually returned to field; therefore fertilizers residue is taken and absorbed by plants that grow on it. Alternative fertilizers are necessary by adding organic fertilizers made out of plant waste, which is oil palm midrib. Sustainable aspect from fertilization can be an initial step toward sustainable oil palm plantation with the hope that the environment will be maintained/sustained with the use of fertilizers made out of plants own parts. Therefore, it will not cause dangerous fertilizers residue effects for plants, soils, and environments in the future.

\section{REFERENCES}

[1] Marihat, Bahan Tanaman Kelapa Sawit Unggul, Pusat Penelitian Kelapa Sawit, PPKS, 2008.

[2] V. I. Sari, Sudradjat, Sugiyanta, "Peran Pupuk Oganik dalam Meningkatkan Efektifitas Pupuk NPK pada Bibit Kelapa Sawit di Pembibitan Utama", J. Agron. Indonesia, vol. 43 no.2, pp. 153-159, 2015.

[3] A. S. Pranata, Meningkatkan Hasil Panen dengan Pupuk Organik. Jakarta (ID), Agromedia Pustaka, 2010.

[4] E.S. Sutarta, Winarna, P. L. Tobing, and Sufianto, "Aplikasi Limbah Cair Pabrik Kelapa Sawit pada Perkebunan Kelapa Sawit”, the paper edited from paper presented in Seminar Efektivitas Aplikasi Pupuk di Perkebunan Pemupukan Kelapa Sawit, Medan, 17-18 July, 2001.

[5] Panduan Teknis Tatacara Pengajuan Proposal Lomba Riset Sawit. (2016) Badan Pengelola Dana Perkebunan Kelapa Sawit..

[6] R. I. Hutagalung, and S. Jalaluddin, Feeds for Farm Animals from the Oil Palm. University Pertanian Malaysia, Malaysia, 1982.

[7] W. Sugiyono, and Darmosarkoro, "Patah Pelepah Kelapa Sawit", Warta PPKS 1998, vol. 6 no.2, pp. 55-61, 1998.

[8] M. Ariyanti, S. Rosniawaty, I.R.D. Anjarsari, A. Fernando, "The Growth Response of Oil Palm Seedling at Main Nursery against Watering at Different Volume and Frequency and Against Provision of Compost," International Journal of Sciences: Basic and Applied Research (IJSBAR), vol. 37, No. 3, pp. 226-233, 2018.

[9] P. Lumbangaol, (2010) Pedoman pembuatan dosis pupuk kelapa sawit buku panduan online..

[10] J. K. Goh, R. Hardter, General Oil Palm Nutrition, International Potash Institute Kassel. Germany, 2010.

[11] Y. Pangaribuan, "Studi Karakter Morfofisiologi Tanaman Kelapa Sawit (Elaeis guineensis Jacq.) di Pembibitan terhadap Cekaman Kekeringan”, thesis, Institut Pertanian Bogor, 2001.

[12] A. S. Parnata, Pupuk Organik Cair Aplikasi \& Manfaatnya, AgroMedia, 2004

[13] Gunawan, E. Ariani, M. A. Khoiri, "Pengaruh pemberian pupuk kandang ayam dan berbagai dosis pupuk urea terhadap pertumbuhan bibit kelapa sawit (Elaeis guineensis Jacq.) di main nursery", Jom Faperta, vol. 1 no. 2, 2014.

[14] K. A. Hanafiah, Dasar-Dasar Ilmu Tanah (Cetakan ke-5), Jakarta: Rajawali Pers, pp. 62-177, 2012.

[15] W. Prawiranata, S. Haran and P. Tjandronegoro, Dasar - Dasar Fisiologi Tumbuhan II, Bogor: Fakultas Pertanian IPB, 1995.

[16] S. M. Sitompul, B. Guritno, Analisis Pertumbuhan Tanaman, Yogjakarta: UGM Press, 1995.

[17] EA. Makinde, Ayeni LS, Ojeniyi SO, "Effects of organic, organomineral and NPK fertilizer treatments on the nutrient uptake of Amaranthus Cruentus (L) on Two Soil Types in Lagos, Nigeria," J Central European Agriculture, vol.12 no.1, pp.114-123, 2011.

[18] Musfal, "Potensi Cendawan Mikoriza Arbuskula untuk Meningkatkan Hasil Tanaman Jagung", Jurnal Litbang Pertanian, vol. 29 no. 4 , pp. 154-158, 2010.

[19] T. Koryati, "Respon pertumbuhan bibit kelapa sawit (Elaeis guineensis Jacq). Akibat penggunaan berbagai jenis pupuk organik dan zat pengatur tumbuh growtone", J Ilmiah Pendidikan Tinggi, vol. 3 no. 3, pp. 1-10, 2010.

[20] F. B. Salisbury, and C.W. Ross, Fisiologi Tumbuhan, Jilid I. Terjemahan Diah R. Lukman. Bandung: Penerbit ITB, pp. 150-176, 1995.

[21] ADJ Jorge, "Pemanfaatan tandan kosong dan abu janjang kelapa sawit sebagai amelioran terhadap pertumbuhan bibit kelapa sawit (Elaeis guineensis Jacq.) di pembibitan utama", thesis, Bogor: Institut Pertanian Bogor, 2012.

[22] H. B Jumin, Dasar-Dasar Agronomi, Jakarta: Rajawali Pers, pp. 249, 2010 .

[23] B. Lakitan, Dasar-Dasar Fisiologi Tumbuhan, Jakarta: Raja Grafindo Persada, 2010. 